JURNAL REKA YASA PROSES
Volume 11 No.2, 2017, hal. 101-105
Journal homepage: http://journal.ugm.ac.id/jrekpros

\title{
Seleksi Isolat Bakteri Amilolitik dari Rhizosfer Canna edulis, Kerr. untuk Produksi Poli Hidroksi Alkanoat dari Limbah Cair Tapioka
}

\author{
Nurhayati $^{1 *}$, Ocky Karna Radjasa ${ }^{2}$, dan Irfan Dwidya Prijambada ${ }^{3}$ \\ ${ }^{1}$ Departemen Biologi Fakultas Sains dan Matematika Universitas Diponegoro, Jl. Prof. Soedarto \\ Semarang \\ ${ }^{2}$ Departemen Perikanan dan Kelautan Universitas Diponegoro, Jl. Prof. Soedarto Semarang \\ ${ }^{3}$ Lab. Mikrobiologi Tanah dan Lingkungan Fakultas Pertanian Universitas Gadjah Mada \\ *Alamat korespondensi: nur_setyahayati@yahoo.com
}

(Submisi: 1 November 2017; Revisi: 1 Desember 2017; Penerimaan: 15 Desember 2017)

\begin{abstract}
A B S T RA C T
Petrochemical-based plastic waste accumulated in landfills have been posing serious threat to the environment as this kind of plastics are non-biodegradable. Replacing petrochemical-based plastics with biodegradable plastics constitutes a challenging solution both in terms of mechanical design of the process and most importantly the availability of powerful local microorganism for the process. Therefore, the current study was searching for appropriate local isolates of microorganisms for poly hydroxyl alkanoate (PHA) production from starch waste, which was considered as one of cheap carbon sources. Waste water of cassava industry is a good resource of such starch waste water. The microbes were isolated from Canna edulis, Kerr. rhizosphere from Cangkringan. The expected isolates were the bacteria enable the coupling of carbon catabolic pathways with PHA anabolic pathways. It was found that ten isolates were able to use waste water of cassava flour industry as carbon source. The PHA quantitative analysis by spectrophotometer showed that the isolate of Bacillus sp. C8 produced the highest PHA of $2.10 \mathrm{~g} / \mathrm{L}$. Further FTIR analysis showed specific bands near $1363.67 \mathrm{~cm}^{-1}, 1641.42 \mathrm{~cm}^{-1}, 2929.87 \mathrm{~cm}^{-1}, 3408.22 \mathrm{~cm}^{-1}$ wavelengths which revealed the presence of $\mathrm{CH}_{3}$, ester carbonyl group $(\mathrm{C}=\mathrm{O}), \mathrm{C}-\mathrm{H}$ and terminal $\mathrm{OH}$ group of $\mathrm{PHA}$.
\end{abstract}

Keywords : Canna edulis, Kerr. rhizosphere, wastewater cassava industry flour, PHA, bakteri

\begin{abstract}
A B S T R A K
Akumulasi sampah plastik berbasis petrokimia di tempat pembuangan sampah mengganggu lingkungan karena plastik sifatnya tidak mudah didegradasi secara biologi dan sangat tahan di lingkungan. Penggantian plastik yang berasal dari bahan petrokimia dengan bahan plastik yang mudah terdegradasi secara biologi merupakan tantangan tersendiri, baik dari sisi perancangan proses maupun ketersediaan mikrobia lokal yang sesuai untuk proses tersebut. Oleh karena itu, penelitian ini dilakukan sebagai upaya untuk mendapatkan bakteri isolat lokal penghasil PHA yang mampu mengkonsumsi substrat berupa pati. Substrat pati dipilih karena ketersediaan limbah industri tapioka sebagai bahan baku potensial dan murah untuk produksi PHA. Bakteri amilolitik untuk produksi PHA telah berhasil diisolasi dari rhizosfer Canna edulis, Kerr. di Cangkringan, Sleman, Yogyakarta, Indonesia. Bakteri yang diisolasi merupakan bakteri dengan kemampuan memproduksi PHA dan memiliki kemampuan melakukan rangkaian reaksi pada limbah cair industri tapioka dan rangkaian
\end{abstract}


reaksi pembentukan PHA. Telah berhasil didapatkan 10 bakteri yang memiliki aktivitas amilolitik dan dapat menghasilkan PHA menggunakan limbah cair industri tapioka. Analisis kuantitatif PHA menggunakan spektrofotometer menunjukkan bahwa isolat Bacillus sp. C8 menghasilkan PHA paling tinggi sebesar 2,10 mg/mL. Analisis hasil metabolism isolat C8 menggunakan FTIR memperlihatkan puncak spesifik $1363,67 \mathrm{~cm}^{-1}, 1641,42 \mathrm{~cm}^{-1}, 2929,87 \mathrm{~cm}^{-1}, 3408,22 \mathrm{~cm}^{-1}$ adalah verifikasi adanya $\mathrm{CH}_{3}$, $\mathrm{C}=\mathrm{O}, \mathrm{C}-\mathrm{H}$ dan $\mathrm{OH}$ dari PHA.

Kata kunci : Canna edulis, Kerr. rhizosfer, limbah cair industri tapioka, PHA, bakteri

\section{Pendahuluan}

Kebanyakan jenis plastik yang banyak digunakan saat ini berbahan dasar senyawa turunan minyak bumi sehingga bersifat sulit terdegradasi oleh mikroorganisme pembusuk di alam. Akibatnya, sampah plastik terakumulasi semakin banyak dengan makin tingginya tingkat penggunaan plastik dalam kehidupan sehari-hari. Untuk mengurangi timbunan sampah plastik, diperlukan bahan plastik pengganti yang ramah lingkungan, yaitu plastik yang dapat diuraikan mikroorganisme pembusuk dalam waktu yang relatif singkat (biodegradable plastic). Salah satu jenis plastik ramah lingkungan ini adalah polyhydroksialkanoate (PHA).

Molekul polimer PHA adalah biopoliester berupa granula yang dapat diproduksi oleh bakteri tertentu. Kebanyakan substrat yang digunakan bakteri pembentuk plastik ini adalah glukosa. Hal ini akan menjadikan biaya tinggi untuk bahan baku dan mengurangi keekonomian produksi PHA. Oleh karena itu, pengembangan bahan plastik ramah lingkungan di Indonesia sebaiknya dimulai dengan melakukan isolasi bakteri lokal yang mampu menggunakan substrat murah, misalnya limbah dengan kandungan pati, seperti limbah industri tapioka yang jumlahnya sangat banyak di berbagai pelosok Indonesia.

Komponen utama limbah cair tapioka adalah amilum sehingga diperlukan isolat bakteri yang memiliki aktivitas amilolitik sekaligus dapat menghasilkan PHA. Pada penelitian sebelumnya, telah dilakukan upaya untuk mencari bakteri amilolitik lokal Indonesia yang memiliki kemampuan menghasilkan PHA (Nurhayati dkk., 2017). Sumber isolat yang digunakan adalah rhizosfer Canna edulis, Kerr. dengan pertimbangan kandungan pati dalam umbi tanaman ini yang cukup tinggi sehingga kemungkinan cukup besar menemukan bakteri amilolitik pada rhizosfer.

Pada penelitian sebelumnya, Nurhayati dkk. (2017) telah menyeleksi isolat-isolat dari rhizosfer Canna edulis, Kerr. dengan analisis gen REP-PCR sehingga dihasilkan 10 isolat terbaik. Penelitian ini merupakan tahap lanjutan yang bertujuan untuk menguji aktivitas amilolitik 10 isolat tersebut untuk membandingkan kemampuan isolat dalam menggunakan sumber karbon berupa pati dalam produksi PHA. Aktivitas amilolitik bakteri pada sumber karbon limbah tapioka dapat diukur berdasarkan gula pereduksi yang dihasilkan. Bakteri yang memiliki kemampuan menghasilkan gula pereduksi pada limbah cair tapioka perlu dianalisis lebih lanjut kemampuannya dalam menghasilkan PHA. Berdasarkan kemampuan menghasilkan gula pereduksi maka dapat dipilih bakteri yang memiliki potensi untuk menghasilkan PHA untuk pengembangan bahan plastik ramah lingkungan. Pemilihan bakteri pada tingkat metabolomik berdasarkan kemampuan menghasilkan gula pereduksi dan kemampuan menghasilkan PHA merupakan cara efektif untuk menskrining bakteri yang potensial untuk produksi PHA pada skala komersial.

Dari hasil penelitian ini diharapkan diperoleh isolat lokal yang mudah diisolasi dari area di Indonesia yang relevan dengan sumber karbon utama yang akan dijadikan substrat. Dengan ketersediaan isolat lokal, maka kendala terbesar produksi bioplastik selama ini, yaitu kebutuhan impor mikroorganisme, bisa diatasi sehingga bisa menurunkan biaya produksi. 


\section{Metode Penelitian}

Isolasi bakteri amilolitik penghasil PHA menggunakan sampel tanah dari rhizosfer Canna edulis, Kerr. di Cangkringan, Sleman, Yogyakarta. Sampel tanah sebanyak 1g dimasukkan ke dalam larutan garam fisiologis steril $\mathrm{NaCl}$ (Merck) 0,05\% dalam kondisi steril secara aseptis. Selanjutnya pengenceran seri 10 kali dituang ke dalam medium amilum agar (Oxoid). Masing-masing isolat yang telah teridentifikasi dalam penelitian sebelumnya sebagai isolat yang memiliki aktivitas amilolitik ditumbuhkan kembali dalam medium nutrien agar sampai diperoleh isolate yang betul-betul murni.

Sepuluh isolat murni tersebut (kode isolat C1C10) selanjutnya diinokulasikan ke dalam medium limbah cair tapioka $100 \mathrm{~mL}$. Inokulasi dilakukan dalam tabung Erlenmeyer $250 \mathrm{~mL}$ dengan penggojogan $100 \mathrm{rpm}$ dan pengambilan sampel dilakukan setiap hari. Pengamatan sampel yang meliputi analisis produksi gula pereduksi dan kemampuan menghasilkan PHA oleh sepuluh isolat dilakukan setiap hari selama 3 hari.

Analisis gula pereduksi dilakukan dengan menggunakan $1 \mathrm{ml}$ sampel yang ditambahkan dengan $1 \mathrm{ml}$ reagen DNS (Merck, p.a.). Campuran dipanaskan sampai mendidih dan diukur absorbansinya dengan spektrofotometer menggunakan panjang gelombang $570 \mathrm{~nm}$ dan dibandingkan dengan kurva standar glukosa (Baskan et al., 2016).

Pemanenan PHA dilakukan dengan melarutkan pelet sel hasil sentrifugasi menggunakan sonikator (Branson 1510) pada kondisi $22 \mathrm{kHZ}, 65 \mu \mathrm{A}$ selama 3 menit dengan pengaturan 30 detik pemecahan sel dan 30 detik pendinginan berselang seling. Selanjutnya PHA diekstraksi menggunakan kloroform (Merck, p.a.). Kloroform diuapkan pada suhu kamar selama 24 jam sampai didapatkan serbuk PHA yang kering. Analisis kuantitatif PHA dilakukan dengan menambah $\mathrm{H}_{2} \mathrm{SO}_{4}$ (Merck, p.a.) yang menghasilkan asam krotonik. Kandungan asam krotonik diukur menggunakan spektrofotometer UV-VIS pada panjang gelombang $235 \mathrm{~nm}$ (Putra dkk., 2007). Sebagai verifikasi tambahan, analisis gugus fungsi PHA juga dilakukan menggunakan FTIR (Vinish et al., 2015).

\section{Hasil dan Pembahasan}

Gambar 1 dan Gambar 2 menunjukkan bahwa bakteri hasil isolasi dari rhizosfer Canna edulis, Kerr., yaitu strain dengan kode C1-C10, memiliki aktivitas katalitik pada medium limbah cair tapioka. Kemampuan katalitik bakteri hasil isolasi teridentifikasi dari kemampuan isolate untuk menghidrolisis amilum di dalam substrat sebagai sumber karbon utama. Kemampuan bakteri hasil isolasi dalam menghidrolisis limbah cair tapioka dapat dideteksi dari produk gula pereduksi yang dihasilkan. Gambar 1 menunjukkan bahwa seluruh isolat yang digunakan dalam penelitian ini dapat menghasilkan gula pereduksi, yang dalam hal ini adalah glukosa. Konsentrasi glukosa tertinggi dihasilkan oleh isolat C8 yang mengindikasikan bahwa isolat tersebut memiliki aktivitas amilolitik yang relatif paling tinggi dibandingkan sembilan isolat lain yang dipelajari dalam penelitian ini.

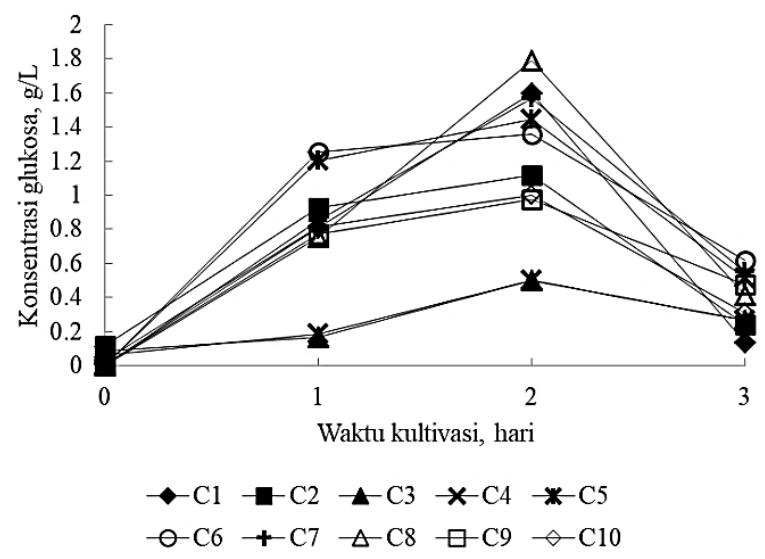

Gambar 1. Produksi glukosa oleh berbagai isolat pada substrat limbah cair tapioka

Gula pereduksi yang dihasilkan berupa glukosa. Glukosa selanjutnya dimetabolisme lebih lanjut oleh bakteri hasil isolasi menjadi PHA. Produksi PHA oleh sepuluh isolat dalam penelitian ini disajikan dalam Gambar 2. 


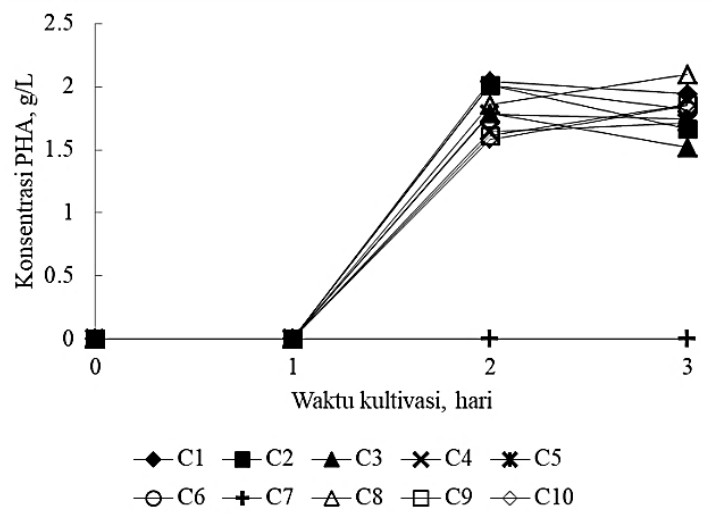

Gambar 2. Produksi PHA (dalam g/L) oleh sepuluh isolat bakteri dari rhizosfer Canna edulis

Gambar 2 menunjukkan bahwa seluruh isolat yang diperoleh dalam penelitian ini memiliki kemampuan menghasilkan glukosa dan sekaligus menghasilkan PHA kecuali isolat C7. Isolat C7 mampu menghasilkan glukosa saja, tetapi tidak berlanjut dengan metabolisme pembentukan PHA.

Gambar 1 dan Gambar 2 menunjukkan bahwa kesepuluh isolat dalam penelitian ini memiliki karakter yang berbeda dalam hal pembentukan glukosa dan PHA. Isolat yang mampu menghasilkan glukosa dalam jumlah cukup banyak, belum tentu memiliki kemampuan yang tinggi pula dalam mengkonversi glukosa tersebut menjadi PHA. Baik karakter memecah amilum menjadi glukosa maupun mengkonversi glukosa menjadi PHA adalah dua karakter yang sama pentingnya dalam proses produksi PHA dari limbah tapioka. Oleh karena itu, dirumuskan parameter produktivitas sebagai acuan pemilihan isolat bakteri yang akan dikembangkan lebih lanjut. Parameter produktivitas dirumuskan secara empiris sebagai hasil kali antara konsentrasi glukosa yang dihasilkan dan konsentrasi PHA yang dihasilkan. Dengan mengacu pada parameter produktivitas ini maka bisa dipilih satu isolat yang relatif paling baik dari kesepuluh isolat yang diteliti.

Tabel 1 menunjukkan nilai parameter produktivitas dari kesepuluh isolat yang dipelajari. Dari nilai-nilai parameter di Tabel 1, dapat disimpulkan bahwa isolat yang memiliki potensi produktivitas terbaik adalah isolat $\mathrm{C} 8$.
Tabel 1. Komparasi isolat bakteri berdasarkan nilai parameter produktivitas

\begin{tabular}{cccc}
\hline Isolat & $\begin{array}{c}\text { Konsentrasi } \\
\text { glukosa (g/L) }\end{array}$ & $\begin{array}{c}\text { Produksi } \\
\text { PHA (g/L) }\end{array}$ & $\begin{array}{c}\text { Parameter produktivitas } \\
\text { (konsentrasi glukosa) x } \\
\text { (produksi PHA) }\end{array}$ \\
\hline C1 & 1,598 & 1,940 & 3,101 \\
C2 & 1,116 & 1,670 & 1,864 \\
C3 & 0,502 & 1,515 & 0,760 \\
C4 & 0,502 & 1,710 & 0.858 \\
C5 & 1,441 & 1,735 & 2,500 \\
C6 & 1,356 & 1,820 & 2,4676 \\
C7 & 1,567 & 0 & 0 \\
C8 & 1,788 & 2,095 & $3,266 *$ \\
C9 & 0,973 & 1,860 & 2,056 \\
C10 & 0,998 & 1,845 & 1,840 \\
\hline
\end{tabular}

Untuk verifikasi lebih lanjut bahwa hasil metabolism isolat C8 adalah PHA, dilakukan analisis gugus fungsi menggunakan FTIR. Hasil analisis produk PHA dari isolat $\mathrm{C} 8$ menggunakan FTIR disajikan dalam Gambar 3 dan komparasi dengan PHA standar (Gatechew dan Woldesenbet, 2016; Giedraityte dan Kalediene, 2016; Diez-pascual dan Diez-vicente, 2014) disajikan pada Tabel 2. Perbandingan dengan standar menunjukkan verifikasi bahwa isolat $\mathrm{C} 8$ mampu mengkonversi glukosa menjadi PHA.

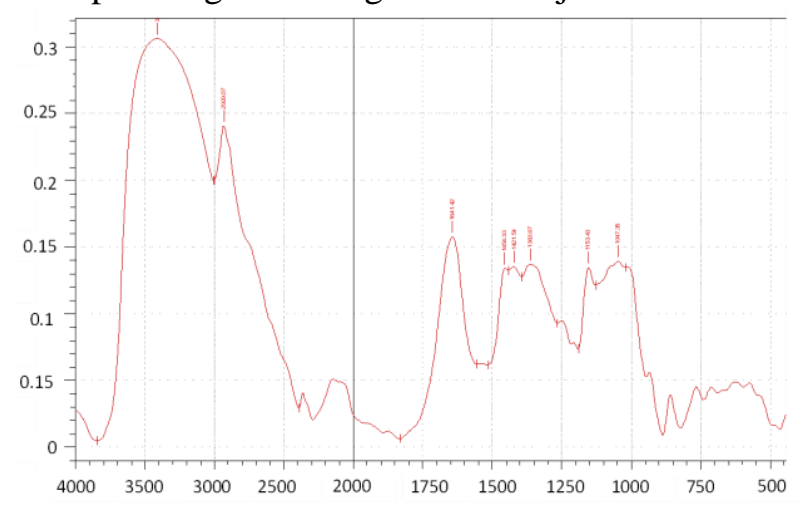

Gambar 3. Hasil analisis FTIR sampel PHA isolat C8

Tabel 2. Gugus fungsi pada PHA hasil isolate C8

\begin{tabular}{ccc}
\hline $\begin{array}{c}\text { Puncak } \\
\text { pada sampel }\end{array}$ & $\begin{array}{c}\text { Puncak } \\
\text { pada standar }\end{array}$ & $\begin{array}{c}\text { Gugus } \\
\text { fungsi }\end{array}$ \\
\hline 1047,35 & 1055,01 & $\mathrm{C}-\mathrm{O}$ \\
1363,67 & 1379,05 & $\mathrm{CH}_{3}$ \\
1454,22 & 1452,35 & $\mathrm{CH}_{2}$ \\
1641,42 & 1732,03 & $\mathrm{C}=\mathrm{O}$ \\
2929,87 & 2933,68 & $\mathrm{C}-\mathrm{H}$ \\
3408,22 & & $\mathrm{O}-\mathrm{H}$ \\
\hline
\end{tabular}




\section{Kesimpulan}

Rhizosfer Canna edulis Kerr. mengandung mikroorganisme amilolitik yang potensial untuk produksi PHA dari limbah yang mengandung amilum. Penelitian ini telah menguji 10 strain hasil isolasi dari rhizosfer Canna edulis Kerr. untuk menyeleksi isolat yang mampu mengkonversi amilum menjadi PHA. Di antara kesepuluh isolat tersebut, diperoleh satu isolat yang relatif paling baik dalam hal produksi glukosa maupun konversi glukosa menjadi PHA, yaitu isolat C8. Keberhasilan isolasi C8 sebagai isolat lokal Indonesia dapat mendorong produksi PHA karena selama ini kendala pengembangan bioplastik di Indonesia adalah bibit mikroorganisme yang harus impor. Oleh karena itu, disarankan isolat C8 perlu dipelajari lebih lanjut dalam bioreaktor yang lebih besar skalanya, untuk menguji stabilitas isolat ini terhadap kondisi proses yang tidak ideal.

\section{Daftar Pustaka}

Baskan K.S., Tutem E., Akyuz E., Ozen S., and Apak R., 2016, Spectrophotometric total reducing sugras assay based on cupric reduction, Tlanta, 147, 162-168.

Diez-Pascual N.H., and Diez-Vicente A.L., 2014, Poly(3-hydroxybutyrate)/ZnO

bionanocomposites with improved mechanical, barrier and antibacterial properties, Int. J. Mol., 15, 10950-10973.

Gatechew A., and Woldensenbet F., 2016, Production of biodegradable plastic by polyhydroxybutyrate (PHB) accumulating bacteria using low cost agricultural waste material, BMC Res., 9, 1-9.

Giedraityfa G. and Kalediene L., 2016. Purification and characterization of polyhydroxybutyrate (PHB) produced from thermophilic geobacillus sp. AY 946034 strain. Chemija 26(1) 38-45.

Nurhayati, Prijambada I.D., Radjasa O.K., dan Widada J., 2017, Repetitive element palindromic PCR (Rep-PCR) as a genetic tool to study diversity in amylolytic bacteria, Advanced Science Letters, 23, 6458-6461.

Putra, J.A., Wiratni, Syamsiah S., and Redyowati, S., 2007, Kinetics of lysis and extraction of intracellular PHB by Cupriavidus necator (CCUG $52238 \mathrm{~T}$ ) using differential method by $\mathrm{H}_{2} \mathrm{O}_{2}$-chloroform", Seminar Nasional Teknik Kimia UNPAR, April 2007.

Vinish V., Sangetta S.H., Aravand J., Kanmani P., and Sathiskumar T., 2015, Optimizing the nutrient feeding strategy for PHA production by a novel strain of Enterobacter sp., Int. J. Environ. Sci. Technol., 12, 2757-2764. 